\title{
Hotels
}

\section{A review of the European hotel market in 2004}

Received: 18 January 2005

\section{Karen Smith}

is an associate director at HVS International and has considerable experience in hotel valuation and consultancy across the UK, Europe and North Africa. Karen is a chartered surveyor and joined HVS International in 2001.

\section{Adrian Jones}

is the Managing Editor at the London office of HVS International. He began his publishing career with Chapman \& Hall, and joined HVS International in 2000 after a spell working as a freelance editor. Adrian produces HVS's popular weekly electronic newsletter EMEA Hospitality Enews.

\section{Abstract}

The European hotel industry in 2004 ended the year on a positive note - with trading performance, in general, improving across the majority of markets and this recovery is expected to continue for the foreseeable future. Development of new hotels continued apace and the transactions market saw considerable activity, both for single assets and portfolios.

\section{Keywords:}

hotel, RevPAR, brand, transaction, Europe

\section{INTRODUCTION}

In 2004 European hoteliers have at last been able to breathe a sigh of relief as hotel performances across many gateway cities and provincial markets have begun to show positive signs of recovery. For the majority of markets this only represents the recouping of successive losses in the wake of $9 / 11$, foot and mouth and the Iraq war. For others, however, the levels of growth in occupancy and room yields have been more significant. The UK, and London particularly, has experienced the highest rates of occupancy since September 2000, when the industry was setting new performance records at the peak of its cycle. Not to be outdone, key destinations in Eastern Europe have also shown tremendous resilience this year, with a significant growth in RevPAR (revenue per available room) witnessed in Budapest, Prague and Moscow. Table 1 shows the percentage changes in RevPAR in key European markets for yearto-date November 2004 compared with the same period in 2003.

While for some of these markets the figures are disappointing, 
Table I: Changes in RevPAR - Year-to-date November 2004

\begin{tabular}{ll|llll}
\hline \multicolumn{3}{c}{ Falls } & \multicolumn{4}{c}{ Rises } \\
\hline $10 \%+$ & Up to $10 \%$ & Up to $5 \%$ & $6-10 \%$ & $10-20 \%$ & $20 \%+$ \\
Barcelona & Amsterdam & Berlin & Cyprus & Lisbon & Athens \\
Madrid & Dublin & Brussels & Zurich & Budapest & Moscow \\
Geneva & Frankfurt & Helsinki & & Istanbul & \\
Warsaw & Milan & Paris & & London & \\
& Salzburg & Rome & & Malta & \\
& Vienna & Copenhagen & & Prague & \\
& Gothenburg & Stockholm & & & \\
\hline
\end{tabular}

Source: Deloitte \& Touche Benchmark Survey ${ }^{1}$

come since the end of 2003 when only four of the 37 markets tracked by Deloitte ${ }^{2}$ showed any growth in RevPAR at all. Furthermore, the relative stability of the European economy at the moment, combined with healthy hotel development and investment activity, enables one to remain cautiously optimistic as 2005 begins and one can reflect on some of the most important events of 2004.

\section{BRAND EXPANSION}

Europe has continued to see a steady stream of new openings this year. The major international hotel groups have been particularly rigorous in seeking out new locations in the developing hotel markets of Central and Eastern Europe. Accor and Kempinski have gone on a spree in the region this year, with Lithuania being on the top of both of their target development lists. In April, Accor opened its first Novotel in the country (the 159-room Novotel Vilnius) - which was also its 100th hotel in Eastern Europe. Meanwhile, Kempinski signed a management contract on a property that will become the 107-room, five-star Kempinski Hotel Vilnius in 2006.

Kempinski will also be stepping into neighbouring Latvia for the first time, having secured a management contract on the Kempinski Kemeri Palace in April 2004. The 150-room, five-star hotel in the resort of Jurmala is currently undergoing renovation work and should be open by mid-2005. The company must wait a little longer - until 2006 - before it can set foot in Slovakia. By the end of that year, however, the 220-room, five-star Kempinski Hotel River Park in Bratislava and the 117-room Grand Hotel Kempinski Vysoke Tatry in the Tatras mountain village of Strbske Pleso should have opened.

Having scored its Eastern European 'century' in April, Accor went on to announce that the 260-room Ibis Praha Smichov in the Czech capital Prague would be the first of a total of 15 new hotels it would be opening in Central and Eastern Europe by the end of 2005, with a particular focus on the Baltic states. In more recent months rumours have surfaced about Accor having similar development plans for plenty more budget hotels in Romania, 
Poland and Hungary.

It is not just the budget brands that have been flourishing in Eastern European soil over the past 12 months. In May the luxury hotel operator Starwood Hotels and Resorts won the race to become the first international operator to open a five-star hotel in the southern Polish city of Krakow. PKO Bank Polski among others helped make the Sheraton Hotel a reality by together investing a reported $\$ 43 \mathrm{~m}$ in the 233 -room property.

In Russia, the 102-room Renaissance St Petersburg Baltic Hotel recently became Marriott International's sixth hotel in the country. Raffles International, meanwhile, has been developing what will become their first hotel in Russia when the Swissotel Riverside Towers opens in Moscow in May 2005. The new hotel, which will be their 25th Swissotel, is an important step in Raffles' strategy of growing globally through management or lease contracts.

In the four-star sector, two hotel companies have made their respective debuts in Eastern European markets this year. In March NH Hotels headed right for the heart of Budapest in bringing its first hotel to Hungary - the 159-room NH Budapest. Then in July it was announced that Poland will be a new home to Barcelo Hotels and Resorts. Construction work began on the four-star Barcelo Blue City Hotel Warsaw, which the company is taking on under a management contract from 2005.

While 2004 has witnessed a huge influx of major international hotel companies into some of the less developed hotel markets within Europe, the search has also continued for new ways to establish and consolidate brand presence in traditional gateway cities. With ever-decreasing numbers of new-build sites available in many of Europe's most important destinations, hotel companies are being forced to be more creative with their ideas and locations.

Boutique (or lifestyle) hotel branding has continued in 2004 as an ever-popular theme. In October two of the UK's most prominent existing boutique hotel companies, Malmaison and Hotel du Vin, joined together. Malmaison's parent company Marylebone Warwick Balfour purchased Hotel du Vin for $£ 66.4 \mathrm{~m}$ ( $£ 272,000$ per bedroom) and pledged aggressive expansion of both chains. While future plans for Malmaison include European expansion into cities such as Paris, the Hotel du Vin brand is to be targeted at cathedral and university towns within the UK such as York, Durham and Chester. Malmaison recently opened its new 64-room MoulinRouge-inspired hotel in Belfast, which in a former life was known as the McCausland Hotel. Hard labour is currently transforming the former Oxford prison into Malmaison's ninth hotel, and at the Princes Dock in Liverpool planning permission was granted for their tenth property, which will include 41 luxury apartments. The next Hotel du Vin property, meanwhile, has been lined up for Henley-on-Thames with the acquisition of the former Brakspear Brewery. 
In the 'budget boutique' sector, in the spring, Malmaison founder Ken McCulloch opened the first of his 'super budget' hotels in the Dakota chain, with a 92-room property at the Sherwood Business Park near Nottingham. Over the border in Scotland, work is already under way on the next Dakota, a $£ 10 \mathrm{~m}, 132$-room hotel at South Queensferry near Edinburgh which is due for completion in 2005. Fellow Scottish cities Glasgow and Aberdeen have been cited as additional potential sites, along with Newcastle and Leeds.

It is not only Ken McCulloch, however, with their sights set on making boutique hotels more accessible to the masses. Some of the world's largest hotel chains are getting in on the action as they realise the growing potential of this lucrative segment. Choice Hotels, franchiser of eight hotel brands, expects to launch the first of a yet-to-be-named upscale budget brand which it hopes to grow to 400 or 500 properties. First to the post, however, is InterContinental Hotels Group (IHG), which in October launched its seventh brand, 'Hotel Indigo', with the opening of a 140-room hotel in the US city of Atlanta, Georgia, the company's traditional testing ground. The brand is aimed at the mid-market sector, offering guests consistently stylish décor and amenities at affordable prices. Within the next decade IHG hopes to have 200 of the hotels open in high-profile urban markets, although announcements have yet to be made about any development plans in European locations. Starwood Hotels and Resorts, meanwhile, which in July announced that Barcelona would be the ideal first location to launch its luxury boutique-style $\mathrm{W}$ brand in Europe, is also thought to be considering a move into the mid-market sector.

\section{TRANSACTIONS}

The hotel sector in the UK had something more mouthwatering than a chocolate egg to look forward to as Easter approached: the climax of the race to acquire the Savoy Group. Blackstone Group and Colony Capital originally intended to set the pack chasing only Claridge's, but when they saw the interest this one hotel had awakened they decided also to unleash the remaining three: the Savoy, the Connaught and the Berkeley. In the end the former tax inspector Derek Quinlan's consortium held off the Saudi Prince Alwaleed bin Talal, and Quinlan Private became the new owner of the luxury London quartet. The $£ 750 \mathrm{~m}$ outlay also bought the Savoy Theatre and the Simpson's-in-the-Strand restaurant.

The budget end of the UK market saw action too as the summer wore on. The prize on offer here comprised the existing 132 properties in the Premier Lodge portfolio and another nine that were to be constructed. The hotels had been part of Scottish \& Newcastle's managed retail business before passing into the hands of Spirit Group in November 2003. The race was no less exciting, and again was ultimately between two runners: the private equity firm Apax Partners and Whitbread. In July Whitbread announced it had won, the company paying $£ 505 \mathrm{~m}$ for the hotels and an extra 
$£ 31.2 \mathrm{~m}$ for 19 pub restaurants. With the completion of the deal, Whitbread could crown itself undisputed champion of the UK budget hotel market and embark on the process of integrating its new hotels with Travel Inn to create a new brand: Premier Travel Inn.

The British summertime might be said to have belonged to the budget sector. Travel Inn's long-time rival Travelodge also chose July to announce that it was looking to raise at least $£ 400 \mathrm{~m}$ through the sale and leaseback of 136 of its hotels on the UK mainland. Interest in the proposed deal was keen at the time, and perhaps 2005 will see a deal concluded. Meanwhile, Travelodge concluded the acquisition of two central London hotels - the Thistle Hotel Islington and the London Ryan Hotel - for conversion to Travelodge hotels.

Two of the year's more substantial portfolio transactions in continental Europe were announced in the final three months. In September London \& Regional Properties revealed a notable acquisition with the purchase of the hotel property company Dividum and its 32 hotels (5,600 rooms) in Finland. The sellers of a portfolio that had a book value of more than $€ 300 \mathrm{~m}$ were the Finnish firms Nordea, Sampo and Ilmarinen. Then just before Christmas private equity firm LBO France was unveiled as the new owner of 28 Libertel hotels (1,835 rooms) in Paris. ABC Hotels, a joint venture comprising Accor, Blackstone Group and Colony Capital, was the seller. Accor remains the manager of the five largest hotels, all of which will be rebranded as Mercure. The remaining 23 hotels will retain their Libertel name but will be managed by Finhotel, a company that LBO France has created. Not to be outdone, Prince Alwaleed's Kingdom Hotels group recently completed the acquisition of the Savoy from Quinlan Private for an undisclosed sum - the property will soon become Fairmont Hotel's first European hotel.

\section{References}

1. Deloitte and Touche (2004) Monthly Bulletin for Europe, Hotel Benchmark Survey, Deloitte and Touche, London, UK.

2. Ibid 